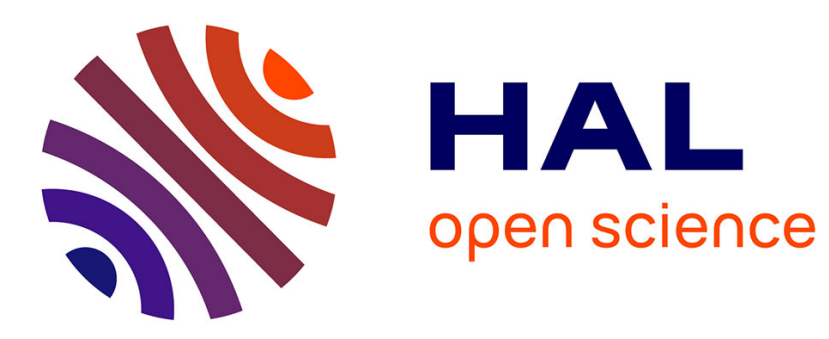

\title{
Nonlinear estimation of aquifer parameters from surficial resistivity measurements
}

\author{
K. P. Singh
}

\section{To cite this version:}

K. P. Singh. Nonlinear estimation of aquifer parameters from surficial resistivity measurements.

Hydrology and Earth System Sciences Discussions, 2005, 2 (3), pp.917-938. hal-00298656

\section{HAL Id: hal-00298656 \\ https://hal.science/hal-00298656}

Submitted on 10 Jun 2005

HAL is a multi-disciplinary open access archive for the deposit and dissemination of scientific research documents, whether they are published or not. The documents may come from teaching and research institutions in France or abroad, or from public or private research centers.
L'archive ouverte pluridisciplinaire HAL, est destinée au dépôt et à la diffusion de documents scientifiques de niveau recherche, publiés ou non, émanant des établissements d'enseignement et de recherche français ou étrangers, des laboratoires publics ou privés. 
Hydrol. Earth Sys. Sci. Discuss., 2, 917-938, 2005

www.copernicus.org/EGU/hess/hessd/2/917/

SRef-ID: 1812-2116/hessd/2005-2-917

European Geosciences Union

of aquifer parameters

K. P. Singh

\section{Nonlinear estimation of aquifer parameters from surficial resistivity measurements}

\section{K. P. Singh}

National Geophysical Research Institute, Uppal Road, Hyderabad-500007, India

Received: 25 February 2005 - Accepted: 19 May 2005 - Published: 10 June 2005

Correspondence to: K. P. Singh (kps_ngri@yahoo.com)

(C) 2005 Author(s). This work is licensed under a Creative Commons License.

Title Page

Abstract

Conclusions

Tables

14

$\triangleleft$

Back

Full Screen / Esc

Print Version

Interactive Discussion 


\section{Abstract}

The present study is focused on an examination of the correlation relationships for hydraulic permeability and transmissivity with electrical resistivity in a range of fractured and alluvial aquifers. The observed permeability data for fractured rock aquifers 5 at some locations is correlated nonlinearly with electrical resistivity of the aquifers estimated from resistivity sounding data and it is found that the permeability of the aquifer in this region exponentially decreases with increase in resistivity. Permeability of the hard rock aquifer within the weathered zone and alluvium aquifers increases exponentially with increase in resistivity, and transmissivity decreases exponentially. However, we of fracture rock and sandwiched aquifers, transmissivity increases exponentially with increase in resistivity. An attempt has been made to find general functional relationship between hydraulic parameters and resistivity of the aquifer, and therefore, published and observed data from India and other parts of the world has been taken under consideration. It is found that for fracture rock and alluvium aquifers, permeability 15 and the transmissivity are best defined as the exponential functions of aquifer resistivity. The application of electrical parameters obtained from resistivity data for evaluation of hydraulic parameters has been demonstrated in detail within the Osmania University Campus, Hyderabad (India). The empirical relations between aquifer parameters and resistivity are established for transforming resistivity distribution into permeability and transmissivity of the aquifer. The information thus obtained from resistivity data on permeability of the aquifer and transmissivity distribution in the study area can be used for optimal use and assessment of water resources.

\section{Introduction}

The hydraulic characteristics of subsurface aquifers are important properties for both groundwater and contaminated land assessments, and also for safe construction of civil engineering structures. Hydraulic conductivity/permeability $(K)$, Transmissivity $(T)$,

\section{HESSD}

2, 917-938, 2005

Nonlinear estimation of aquifer parameters

K. P. Singh

Title Page

Abstract Introduction

Conclusions

Tables

References

Figures

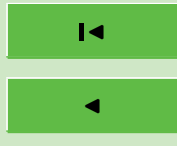

$\rightarrow$

Back

Close

Full Screen / Esc

Print Version

Interactive Discussion

EGU 
and Storativity $(S)$ are all commonly applied hydraulic parameters in groundwater flow modelling (Freeze and Cherry, 1979; Fitts, 2002). Application of field hydrogeological methods of assessment is a standard technique for evaluating these aquifer properties, however estimating $K, T$, and $S$ values from field pumping tests and downhole well-log 5 data can be very expensive and time-consuming. In this context, surface geophysical methods may provide rapid and effective techniques for groundwater exploration and aquifer evaluation. Application of geophysical methods generally is proving very effective for water content estimation, water quality assessment and mapping of the depth to the water table and bedrock (Hubbard and Rubin, 2002). Although various geophys10 ical techniques currently are being applied to explore and assess water resources, the DC electrical resistivity method still proves the most powerful and cost-effective. Use of Wenner and Schlumberger array vertical electrical sounding (VES), profiling, and also electrical tomography techniques have become very common in groundwater exploration and contamination studies, and there are standard, published direct and indirect 15 interpretation techniques specifically for VES data (cf. Jupp and Vozoff, 1975; Koefoed, 1979). Recently, attempts have been made by researchers also to obtain such hydraulic parameter estimates from resistivity measurements (e.g. Brace, 1977; Biella et al., 1983; Bussian, 1983),

In porous media and alluvial aquifers per se, transmissivities, formation factors and permeability can be estimated using empirical/semi-empirical correlations, often using simple linear relations (Kelly, 1977a, b; Heigold et al., 1979; Schimschal, 1981; Urish, 1981; Chen and Hubbard et al., 2001). In the present study, Schlumberger resistivity soundings have been assessed in both alluvial (porous medium) and fractured hard rock aquifers for possible relationships with hydraulic parameters. Particularly in frac25 tured and fissured hard rock regions delineation of aquifer properties by geophysical methods can be a very difficult task. For example, if the conductive aquifer is thin and sandwiched between two electrically resistive layers then no indication of its presence will be observed in a resistivity sounding curve (Singh, 2003a). Moreover, groundwater flow in fractured aquifers is very complicated, and accuracy in estimation of the hy-
HESSD

2, 917-938, 2005

\section{Nonlinear estimation of aquifer parameters}

K. P. Singh

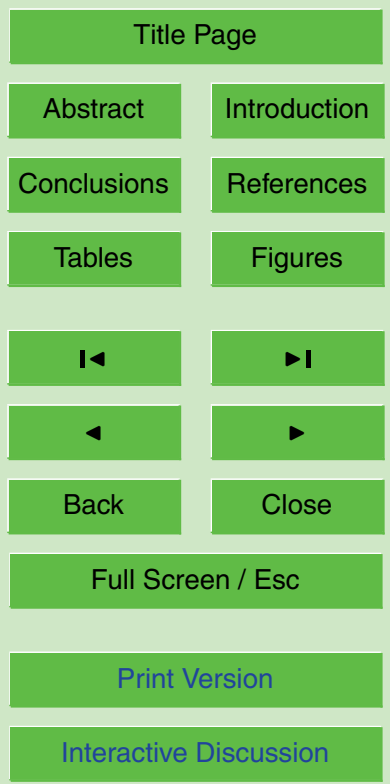

EGU 
draulic parameters depends on the hydraulic behavior in particular fractures, which is site specific. In such situations, non-conventional methods may be useful to detect a hidden aquifer (Singh, 2003a).

\section{Theoretical foundations}

5 The theory of and mathematical expressions used for exploration of groundwater by geoelectrical methods are well established (e.g. Bhattacharya and Patra, 1968; Koefoed, 1979; Keller and Frischknecht, 1966). The Schlumberger array method of Vertical Electric Sounding (VES) has been applied both for obtaining the electrical resistivity structure of the shallow earth and for exploring for groundwater (Fig. 1). The depth of investigation in a Schlumberger sounding configuration typically varies between $0.25 \mathrm{AB}$ to $0.5 \mathrm{AB}$ (Roy and Elliot, 1981).

Mathematically, electrical current flow $(J)$ in a conducting medium is governed by Ohm's law and groundwater flow in a porous medium Darcy's law, both having similar forms of equation:

${ }_{15} J=-\sigma \frac{d V}{d r}$

$q=-K \frac{d h}{d r}$

where $J, \sigma, V, r, q, K, h$ are respectively the current density (amps per unit area), electrical conductivity (Siemens $/ \mathrm{m}=$ reciprocal resistivity, $\rho$ ohm.m or $\Omega . \mathrm{m}$ ), electrical potential (volts), distance (metres), specific discharge (discharge per unit area), 20 hydraulic conductivity (or permeability; $\mathrm{m} / \mathrm{s}$ ) and hydraulic head $(\mathrm{m})$. The analogy between these two macroscopic phenomenona is widely accepted (Freeze and Cherry, 1979; Fitts, 2002). Thus, the electrical method provides a powerful analogue and tool for groundwater exploration and modelling, and may be useful e.g. in generating analytic flow nets.

\section{Nonlinear estimation of aquifer parameters}

K. P. Singh

\section{Title Page}

Abstract Introduction

Conclusions References

Tables Figures

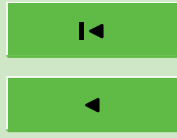

$\rightarrow$

Back

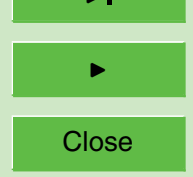

Full Screen / Esc

Print Version

Interactive Discussion

EGU 
For homogeneous and isotropic medium, electric current and groundwater flow both satisfy the Laplace equation: for electrical flow,

$\frac{d^{2} V}{d r^{2}}+\frac{2}{r} \frac{d V}{d r}=0$

and for groundwater flow,

${ }_{5} \frac{d^{2} h}{d r^{2}}+\frac{1}{r} \frac{d h}{d r}=0$.

2, 917-938, 2005

Nonlinear estimation of aquifer parameters

K. P. Singh

For a point current source, the solution of Eq. (3) in a semi-infinite, homogeneous medium for (hemispherical earth) electrical flow can be written as

$V=\frac{\rho l}{2 \pi} \frac{1}{r}$

and for hydraulic flow a similar equation can be written as:

${ }_{10} h=\frac{Q}{2 \pi T} \ln r$.

Transmissivity of an aquifer of saturated thickness $b$ then is expressed by

$T=K b$

such, Eq. (4) becomes:

$h=\frac{Q}{2 \pi K b} \ln r$.

15 In general terms, since larger connected pores make for better flow characteristics for both water and electric currents it is expected that at the very least there should be some relationship between electrical and hydraulic parameters. Although the previous equations relate to flow in homogeneous earth media, in the present study nevertheless an attempt is made firstly to identify (site-specific) empirical relations in two 
particular aquifer types (alluvial, fissured), and secondly then to identify more general aquifer relations. Moreover, hydrogeological properties of the aquifers in fractured aquifers generally vary rapidly. As a result, directly linear relations between resistivity and hydraulic parameters ( $K$ and $T$ ) do not readily exist. Therefore, in present study, 5 nonlinear relations between resistivity and transmissivity and permeability have been fit.

\subsection{Methodology}

A nonlinear empirical correlation analysis of field hydraulic parameters ( $K$ and $T$ ) with resistivity $(\rho)$ has been performed for a range of published data from aquifer studies 10 in central Japan and Rhode Island (USA), along with observed data from India. The empirical relation between $K$ and $\rho$ obtained in the present study for Osmania University Campus, Hyderabad (India) particularly may be used to compute permeability estimates at other VES locations where $K$ data from pumping tests is not directly available. However, it is potentially a very difficult task to generalise the relationships both

15 to alluvial and fractured aquifers. Transmissivity evaluations based on permeability estimates in the former case may be particularly erroneous if the saturated thickness and electrical resistivity of the aquifer are not interpreted accurately. Thus accuracy in estimation of thickness and resistivity of the aquifer must be adequately maintained while interpreting the VES data, rms error $<5 \%$. Information on thickness of the aquifer is ex20 tracted here using a non-conventional method proposed by Singh (2003a) along with other available information on depth to the water table from existing dug wells in the area. Thickness and resistivity of the aquifer at various observation points are obtained by inversion of VES data. The a priori information available on hydrological parameters and depth of water table from dug wells and bore well is used to constrain and minimize the ambiguity of interpretation. The root mean square (rms) error between observed and computed VES data is maintained less than $5 \%$ while computing the resistivity and thickness of the aquifer by employing inversion scheme proposed by Jupp and Vozoff (1975).

\section{Nonlinear estimation of aquifer parameters}

K. P. Singh

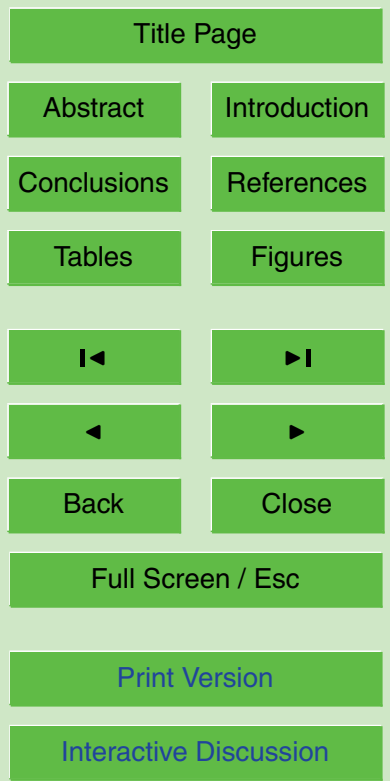

EGU 


\section{Results and discussions}

Interestingly, in all cases permeability and transmissivity prove best correlated with resistivity if a nonlinear, exponential curve is fitted.

\subsection{Alluvium aquifers}

5 Published data on alluvial aquifers from U.P., India (Sriniwas and Singhal, 1985), and Beaver River aquifer and Chipuxet aquifer of the Pawcatuck River basin, Rhode Island, USA (Kosineski and Kelly, 1981) have been used here to examine the empirical relationship between permeability $(K)$ and electrical resistivity $(\rho)$ in these aquifers (Table 1). Permeability is calculated from the published pumping test data for the sites 10 shown in Table 1 (Sriniwas and Singhal, 1985). Subsequently, various functions were tried in the present study to fit the pumping test data by the cited authors for the sitespecific $K$ and $\rho$ values for the alluvial aquifer studies. For the published data on alluvial aquifers, it is found generally that an exponential fit of $K$ on $\rho$ is reasonable. The levels of confidence (standard deviation = SD for all data fits is found to be $>90 \%$ 15 (Figs. 2a-2c). The empirical relations obtained in the different aquifers are:

U.P. India alluvial aquifer data:

Banda Area: $K=2.0345 e^{-0.2458 \rho}$

Varanasi Area: $K=0.0538 e^{0.0072 \rho}$

20 Saharanpur Area: $K=0.0002 e^{0.0897 \rho}$

USA alluvial aquifer data:

Rhode Island, USA: $K=0.0192 e^{0.003}$

Most of the examples of alluvial aquifers show $K$ increases with $\rho$, excepting the Banda Area (Fig. 2a). In the Banda area, the presence of granitic hillocks exposed

\section{HESSD}

2, 917-938, 2005

Nonlinear estimation of aquifer parameters

K. P. Singh

Title Page

Abstract Introduction

Conclusions References

Tables

Figures

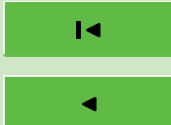

Back

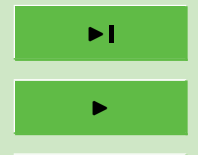

Full Screen / Esc

Print Version

Interactive Discussion

EGU 
at the surface in some locations (Sriniwas and Singhal, 1985) may give rise to a significantly different subsurface geological setting in comparison with the other alluvial aquifers looked at. The presence of hard rock lithologies in the area may be the cause the negative correlation of the variation in permeability with resistivity. This type of be5 havior typically is found in hard rock aquifers (see below). Nevertheless, it is noted that for all of the alluvial aquifers the permeability-electrical resistivity relationship can be fit generally with an exponential function.

\subsection{Hard rock aquifers}

In the present analysis, the permeability $(K)$ and resistivity $(\rho)$ data from published 10 laboratory and borehole measurements at Mount Tsukuba, Central Japan (Sudo et al., 2004) are considered, along with observed data recently measured by the author at the Osmania University Campus (OUC), Hyderabad, A.P., India (Table 2). Both regions are located in granitic host media, and have different climatic condtions/geograhic locations but in both case similar relation between permeability and electrical resistivity of the 15 aquifer is found. The Osmania University Campus (OUC) is a granitic hard rock region of Hyderabad, A.P., India (Fig. 4). Granitic soils and rocks of Archaean age cover the area and the topography follows a gentle slope. Twenty-five VES were conducted at accessible locations across the campus (Fig. 4).

In hard rock aquifer of Central Japan, aquifer permeability exponentially decreases

with resistivity in the intact rock cases but increases with increasing resistivity in the weathered rock cases (Figs. $3 a$ and $3 b$ ). The following two expressions are obtained for weathered $(S D=0.982)$ and intact rock aquifers $(S D=0.980)$ with excellent fit.

For weathered rock aquifers: $K=5 E-08 e^{0.0045 \rho}$.

In hard rock aquifer of Central Japan, aquifer permeability exponentially decreases with resistivity in the intact rock cases but increases with increasing resistivity in the weathered rock cases (Figs. $3 a$ and $3 b$ ). The following two expressions are obtained

\section{Nonlinear estimation of aquifer parameters}

K. P. Singh

\section{Title Page}

Abstract Introduction

Conclusions

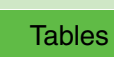

References

Tables

Figures

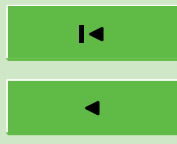

$>1$

Back

Close

Full Screen / Esc

Print Version

Interactive Discussion

EGU 
for weathered $(S D=0.982)$ and intact rock aquifers $(S D=0.980)$ with excellent fit:

For weathered rock aquifers: $K=5 E-08 e^{0.0045 \rho}$

2, 917-938, 2005

and for intact aquifers: $K=1945.6 e^{-0.0055 \rho}$

The OUC study (India) also shows a decreasing $K$ with increasing $\rho$ values. From 5 in situ measurements, it is observed that the shallow (weathered rock) aquifers in the OUC, India are dry and no pumping test data is available for them. Thus, correlation analysis of $\rho$ and $K$ directly of the shallow aquifers in weathered zone could not be performed as for the central Japan study. However, $\rho$ and $K$ data of an identified aquifer sandwiched between resistive or less permeable layers within depth range 10-30 m do correlate nonlinearly, and $K$ exponentially decreases with increasing $\rho$ (Fig. 3c) and the expression for this dependency is given by:

OUC granitic aquifer: $K=8 \times 10^{-6} e-0.0013 \rho$

Generally, the aquifer in the OUC is found to be sandwiched between two resistive layers (Singh, 2003b). The transmissivity of the homogeneous aquifer then can be 15 expressed as the product of the saturated thickness of the aquifer and permeability, such that:

$T=8 \times 10^{-6} e--^{0.0013 \rho} b$

Equations (15) and (13) then are used to convert resistivity distribution of the aquifer to transmissivity estimates for the OUC, India.

20 In more general terms, using a nonlinear, exponential fit there is the possibility of identifying generalised equation for the variation of $\mathrm{K}$ with $\rho$.

$K=A e^{B \rho}$

For intact, unweathered aquifers, $A>0, B<0$; and $B>0$ for alluvium or weathered rock aquifers, for which $A$ and $B$ are site dependent constants. This nonlinear correlation

\section{Nonlinear estimation of aquifer parameters}

K. P. Singh

Title Page

Abstract Introduction

Conclusions References

Tables

Figures

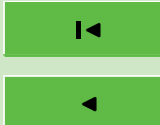

Back

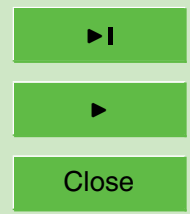

Full Screen / Esc

Print Version

Interactive Discussion

EGU 
study also reveals that the permeability decreases exponentially if an aquifer is sandwiched between two highly resistive layer, but increases with increase in resistivity of the aquifer, if the aquifer is just underlying or within weathered rock.

An empirical relation is obtained by correlating observed permeability and resistivity 5 of the aquifer that are estimated from VES data. This equation is used to transform resistivity into permeability of the aquifer in OUC. Equation (13) can be rewritten in general form as given below:

$T=A e^{-B \rho}$

Where $A\left(=8 \times 10^{-6} \mathrm{~h}\right)$ and $B$ are the site dependent constants for a particular aquifer, 10 and can be determined by using available information of permeability and resistivity of the particular area.

The results obtained from the interpretation of VES data reveal that the depth of potential aquifers varies from 10 to $30 \mathrm{~m}$ in OUC (Singh, 2003b). The resistivity distribution of aquifers shown in Fig. 5 shows high values (160-360 ohm-m) around TA

15 (Tagore Auditorium) and LIB (library). These high $\rho$ value(s) are observed close to the sandwiched aquifer and where the overlying resistive layer has considerable thickness $(>5 \mathrm{~m})$. Such aquifers are found however to be high yielding at the time of drilling and some bore well subsequently have dried after some time after drilling; such aquifers are not adequately recharged due the presence of high resistive (less permeable) layer.

20 The yield of the bore well can be computed from derived geoelectrical parameters like Dar Zarrouk parameters (Singh, 2003b, 2004). The resistivity data is transformed into transmissivity $(T)$ using Eq. (17). The transmissivity image of the aquifer within depth range $5-30 \mathrm{~m}$ is shown in Fig. 4.

The transmissivity varies from $10^{-3}$ to $10^{-2} \mathrm{~cm}^{2} / \mathrm{s}$. Dried bore wells are found in the 25 low transmissivity $\left(\sim 10^{-3} \mathrm{~cm}^{2} / \mathrm{s}\right)$ parts of OUC near VCL, TA and south-west of LIB. The yield of the existing bore wells at some locations nearby VES (Table 3) can be compared with resistivity data by Singh (2003b). The yielding wells are found in the areas of high transmissivity $\left(9 \times 10^{-3}\right.$ to $\left.2.1 \times 10^{-2} \mathrm{~cm}^{2} / \mathrm{s}\right)$ near NCC office $\left(6.95 \mathrm{~m}^{3} / \mathrm{h}\right)$

2, 917-938, 2005

\section{Nonlinear estimation of aquifer parameters}

K. P. Singh

\section{Title Page}

Abstract Introduction

Conclusions References

Tables Figures

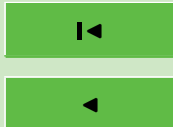

I

Back

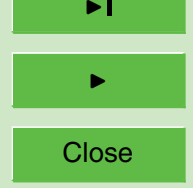

Full Screen / Esc

Print Version

Interactive Discussion

EGU 
and Landscape garden $\left(7.27 \mathrm{~m}^{3} / \mathrm{h}\right)$. Thus, the site observations support the computed estimation of transmissivity distribution of the aquifer from the OUC data.

\section{Conclusions}

The present study reveals that the permeabilities of hard rock and alluvium aquifers 5 vary exponentially with resistivity. From the field examples of India and other parts of the world discussed in present study, it is concluded that the permeability increases in weathered hard rock and alluvium aquifers and decreases as the aquifer resistivity increases within intact rock aquifers. In present area, the resistivity distribution of the aquifer is converted into transmissivity using Eq. (17). In present study the uncertainity 10 is minimized using nonconventional method of interpretation of VES data. This approach can be applied in other parts of the hard rock and alluvium aquifers of India and other parts of the world. This transformation can be used to convert electrical resistivity imaging/tomography data into permeability/transmissivity. This will provide valuable information for flow modeling and recharge of groundwater, and in finding suitable sites 15 for construction of safe civil engineering structures in the study area where less permeability or transmissivity zone are of the interest. However, before generalizing this approach as described in Eqs. (17) and (18), geophysical and hydrogeological study should be carried out at large scale. The study of permeability and transmissivity of near surface unsaturated weathered rock would be very helpful for finding suitable sites for studies of recharge, contamination and dewatering of aquifers.

Acknowledgements. The author is thankful to Director, National Geophysical Research Institute for his permission to publish this work. I am very thankful to T. Elliot, Queen's University, Northern Ireland for improving English of the paper and for his constructive technical suggestions. I am also grateful to anonymous reviewers and editor in chief for their careful reading and

\section{Nonlinear estimation of aquifer parameters}

K. P. Singh

\section{Title Page}

Abstract Introduction

Conclusions

Tables References

Figures

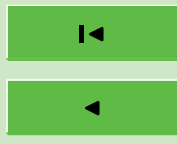

$>1$

Back

Close

Full Screen / Esc

Print Version

Interactive Discussion

EGU 


\section{References}

Bhattacharya, P. K. and Patra, H. P.: Direct current geoelectric sounding, Elsevier Science Publications, 4-7, 1968.

Biella, G., Lojez, A., and Tabacco, I.: Experimental study of some of hydrogeophysical properties of unconsolidated media, Ground Water, 21, 741-751, 1983.

Brace, W. F.: Permeability from resistivity and pore shape, J. Geophys. Res., 82, 23, 334-339, 1977.

Bussian, A. E.: Electrical conductance in porous medium, Geophysics, 48, 1258-1268, 1983.

Fitts, C. R.: Groundwater Science, Elsevier Science Publications, The Netherlands, 167-175, 2002.

Freeze, R. A. and Cherry, J. A.: Groundwater. Prentice- Hall, Inc., Englewood Cliffs, N.J, 1979.

Chen, J., Hubbard, S., and Rubin Y.: Estimating Hydraulic Conductivity at the South Oyster Site from Geophysical Tomographic Data using Bayesian Techniques based on the Normal Linear Regression Model, Wat. Resour. Res., 37, 6, 1603-1613, 2001.

15 Jupp, D. L. V. and Vozoff, K.: Stable iteration method for inversion of geophysical data, Geophys. J. Roy. Astr. Soc. 42, 957-976, 1975.

Heigold, P. C., Gilkeson, R. H., Cartwright, K., and Reid, P. C.: Aquifer transmissivity from surficial electrical methods, Ground Water, 17, 330-345, 1979.

Hubbard, S. and Rubin, Y.: Hydrogeophysics: State-of-the-Discipline, EOS v. 83, 51, 602, 606, 2002.

Jupp, D. L. V. and Vozo, K.: Stable iteration method for inversion of geophysical data, Geophys. J. Roy. Astr. Soc., 42, 957-976, 1975.

Keller, G. V. and Frischknecht, F. C.: Electrical methods in geoelectric prospecting, Pergamon Press, 90-04, 1966.

Kelly, W. E.: Electrical resistivity for estimating permeability, J. Geotech. Eng. Div, 103, 11651168, 1977a.

Kelly, W. E.: Geoelectrical sounding for estimating aquifer hydraulic conductivity, Ground Water, 50, 6, 420-425, 1979b.

Koefoed, O.: Geosounding Principle-1, Elsevier Science Publications Amsterdam, The Netherlands, 170-181, 1979.

Roy, K. K. and Elliot, H. M.: Some observations regarding depth of exploration in DC electrical methods, Geoexploration, 19, 1-13, 1981.

\section{HESSD}

2, 917-938, 2005

\section{Nonlinear estimation}

of aquifer parameters

K. P. Singh

\section{Title Page}

Abstract

Introduction

Conclusions

References

Tables

Figures

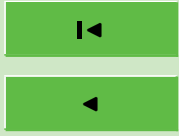

$\rightarrow$

Back

Close

\section{Full Screen / Esc}

Print Version

Interactive Discussion

EGU 
Singh, K. P.: A New Approach for Detection of Hidden Aquifer Using DC Resistivity Data Transforms, J. Geolog. Soc. India, 61, 540-548, 2003a.

Singh, K. P.: Geo-electrical exploration for groundwater in a Hard Rock Region of Hyderabad, India, First Break, 21, 29-34, 2003b.

5 Singh, K. P.: A First Attempt for determination of relationships between geophysical parameters and yield of the aquifers. Presented in 91st conference of ISC, 3-7 January Punjab University, Chandigarh, India, 2004.

Sri Niwas, Singhal, D. C.: Aquifer transmissivity of porous media from resistivity data, J. Hydrol., 82, 143-153, 1985.

10 Sudo, H., Tanaka, T., Kobyasi, T., Konado, T., Miyamoto, M., and Amagai, M.: Permeability imaging in granitic host rocks based on surface resistivity profiling, Explor. Geophys., 57, 1, 56-61, 2004.

Urish, D. W.: Electrical resistivity: Hydraulic conductivity relationships in glacial out wash aquifers, Wat. Resour. Res., 17, 1401-1408, 1981.

Zhdanov, S. M. and Keller, G.V.: The geoelectric methods in geophysical exploration, Elsevier Science Publications, Amsterdam B.V., The Netherlands, 1994.

HESSD

2, 917-938, 2005

Nonlinear estimation

of aquifer parameters

K. P. Singh

Title Page

Abstract

Introduction

Conclusions

References

Tables

Figures

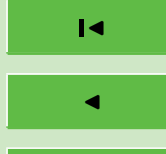

$\rightarrow$

Back

Close

Full Screen / Esc

Print Version

Interactive Discussion 
Table 1. The resistivity and pumping test data of alluvium aquifers U.P. (after Sriniwas and Singhal, 1985) and Rhode Island, USA (after Kosinsky and Kelly, 1981).

\begin{tabular}{llll}
\hline Area & \multicolumn{3}{l}{ Alluvium Aquifers } \\
& S.N. & $\begin{array}{l}\rho \\
(\mathrm{Ohm}-\mathrm{m})\end{array}$ & $\begin{array}{l}\mathrm{K} \\
(\mathrm{cm} / \mathrm{s})\end{array}$ \\
\hline 1. Banda Area, U.P., India & 1. & 19.9906 & 0.01346 \\
& 2. & 15.2497 & 0.04612 \\
& 3. & 18.7243 & 0.02112 \\
& 4. & 18.7243 & 0.02269 \\
& & & \\
2. Varanasi Area, U.P., India & 1. & 42.7221 & 0.06424 \\
& 2. & 62.0974 & 0.08704 \\
& 3. & 183.095 & 0.18738 \\
& 4. & 96.5639 & 0.1265 \\
3. Saharanpur Area, U.P., India & & & \\
& 1. & 51.6808 & 0.02431 \\
& 2. & 60.5518 & 0.05903 \\
& 3. & 60.6832 & 0.05787 \\
& 4. & 44.3255 & 0.01215 \\
& 5. & 66.3742 & 0.08183 \\
& 1. & 403.86 & 0.04932 \\
4. Rhode Island, USA & 2. & 176.784 & 0.02511 \\
& 3. & 304.8 & 0.06143 \\
& 4. & 114.3 & 0.03297 \\
& 5. & 693.42 & 0.1653 \\
\hline
\end{tabular}

\section{HESSD}

2, 917-938, 2005

Nonlinear estimation of aquifer parameters

K. P. Singh

Title Page

Abstract

Introduction

Conclusions

References

Tables

Figures

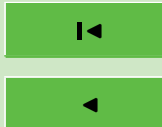

Back

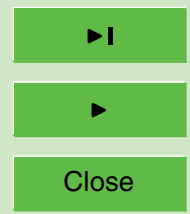

Full Screen / Esc

Print Version

Interactive Discussion

EGU 
Table 2. The resistivity and pumping test data of hard rock aquifers of Central Japan from weathered rock and intact rock aquifers (after Sudo et al., 2004), and Osmania University Campus, Hyderabad (India).

\begin{tabular}{clll}
\hline Area & \multicolumn{3}{l}{ Hard rock Aquifers } \\
\hline & S.N. & $\rho(\mathrm{Ohm}-\mathrm{m})$ & $\mathrm{K}(\mathrm{cm} / \mathrm{s})$ \\
\hline \multirow{3}{*}{ 1. Mt. Tsukuba, Central Japan } & 1. & 2561 & 0.00468 \\
(a) Weathered rock aquifers & 2. & 1511 & $3.4 \mathrm{E}-05$ \\
& 3. & 1275 & $3.9 \mathrm{E}-05$ \\
& 4. & 1061 & $3.2 \mathrm{E}-06$ \\
& 5. & 2300 & 0.00135 \\
& 1. & 2561 & \\
(b) Intact rock aquifers & 2. & 2110 & 0.00468 \\
& 3. & 4575 & 0.0115 \\
& 4. & 4000 & $1 \mathrm{E}-08$ \\
& 5. & 2850 & $1 \mathrm{E}-07$ \\
& & & 0.00057 \\
2. OUC, Hyderabad, A.P. (India) & 1. & 92 & \\
& 2. & 252 & 0.02431 \\
& 3. & 496 & 0.05903 \\
& 5. & 1061 & 0.05787 \\
& 6. & 3500 & 0.01215 \\
& & 5100 & 0.08183 \\
\hline
\end{tabular}

2, 917-938, 2005

Nonlinear estimation of aquifer parameters

K. P. Singh

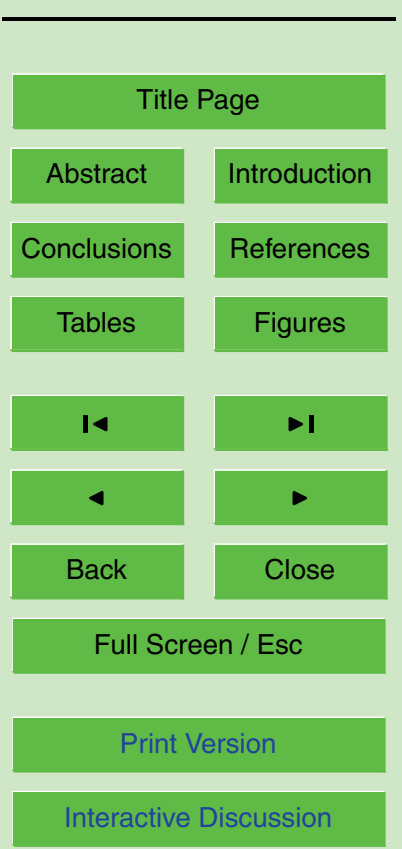

EGU 
2, 917-938, 2005

\section{Nonlinear estimation}

of aquifer parameters

K. P. Singh

Table 3. Yield of the existing bore wells near some VES sites in OUC, Hyderabad (India).

\begin{tabular}{ccc}
\hline S.N. & VES No. & Yield $\left(\mathrm{m}^{3} / \mathrm{h}\right)$ \\
\hline 1. & $\mathrm{~S} 1$ & 6.13724 \\
2. & $\mathrm{~S} 5$ & 6.81915 \\
3. & $\mathrm{S} 7$ & 6.9328 \\
4. & $\mathrm{~S} 11$ & 7.27376 \\
5. & $\mathrm{~S} 14$ & 6.95553 \\
\hline
\end{tabular}

Title Page

Abstract

Introduction

Conclusions

References

Tables

Figures

14

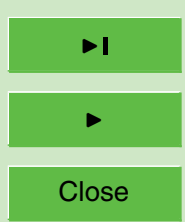

Back

Full Screen / Esc

Print Version

Interactive Discussion

EGU 


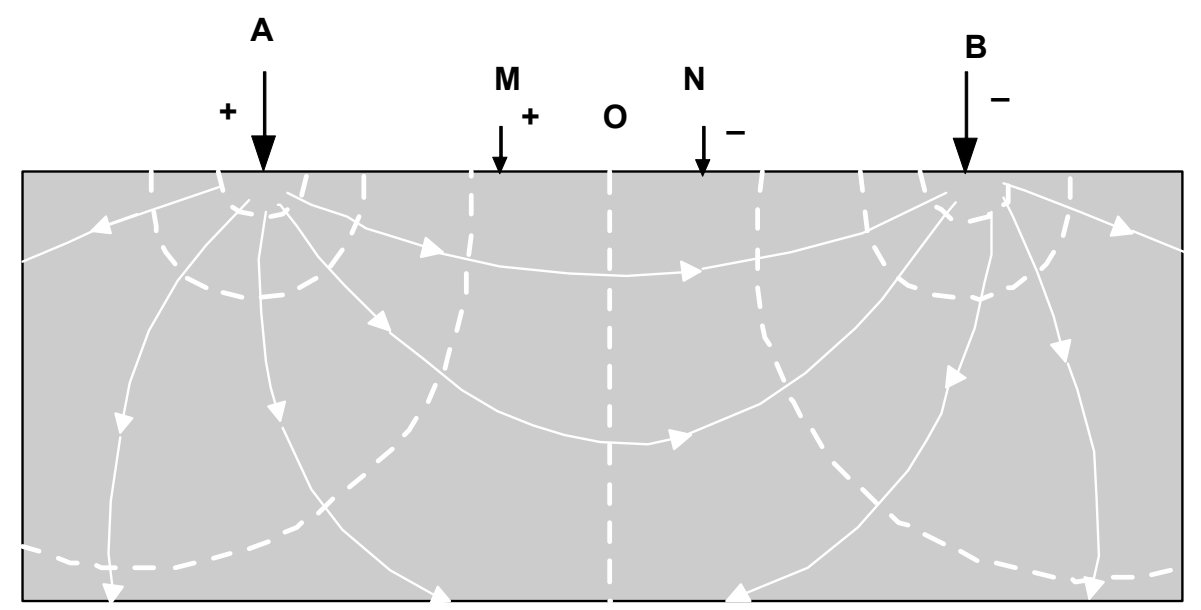

Fig. 1. Schematic diagram of Schlumberger resistivity sounding electrode configuration and principle of current flow in subsurface. The dotted lines (...) represent the equipotent surfaces and solid lines ( - ) direct currents. A and B are the current electrodes, and $\mathrm{M}$ and $\mathrm{N}$ are the potential electrodes.

\section{Nonlinear estimation of aquifer parameters}
K. P. Singh

Title Page

\section{Abstract}

Introduction

Conclusions

References

Tables

Figures

14

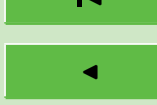

Back

Full Screen / Esc

Print Version

Interactive Discussion 

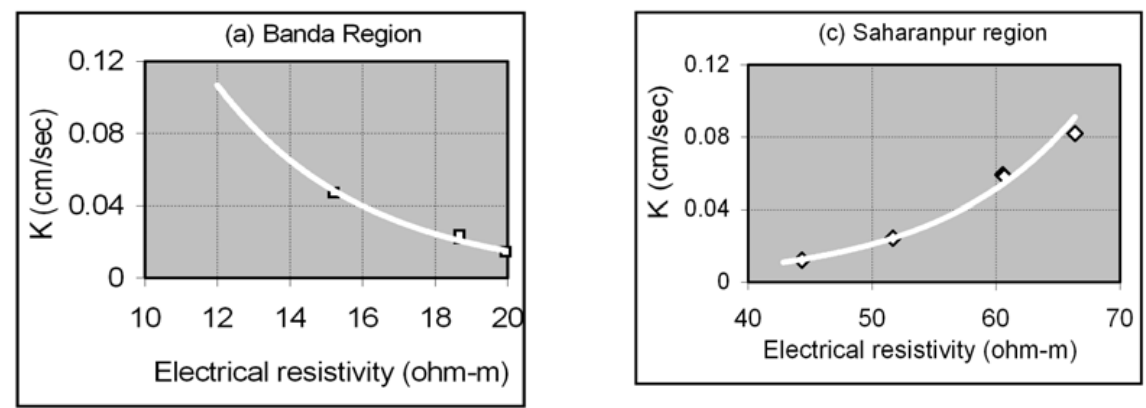

2, 917-938, 2005

\section{Nonlinear estimation of aquifer parameters}

K. P. Singh
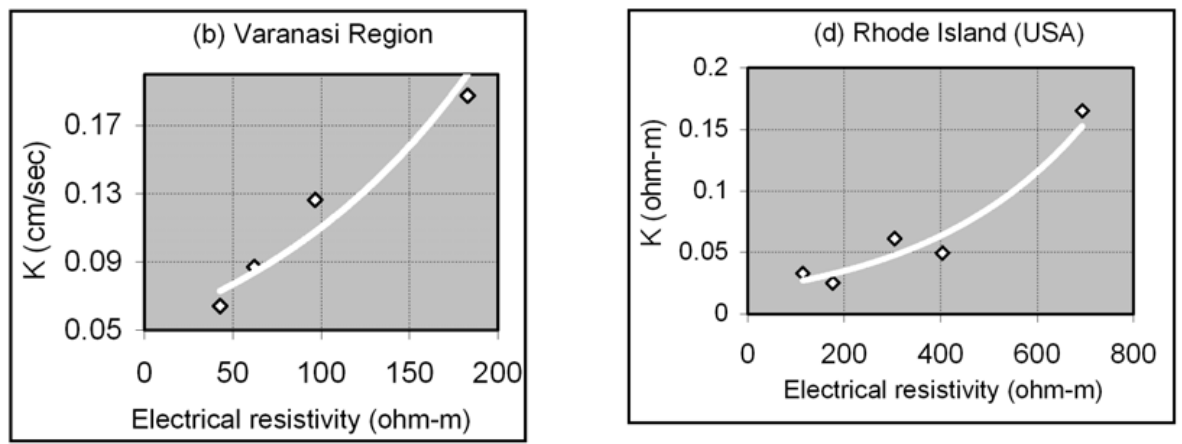

Title Page

Abstract

Introduction

Conclusions

References

Tables

Figures

14

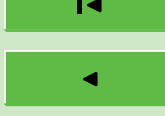

$>1$

Back

Close

Full Screen / Esc

Print Version

Fig. 2. Nonlinear correlation analysis of alluvium aquifers. Permeability $(K)(a)$ decreases with increasing electrical resistivity in Banda Area of U.P., India but increases with increase in resistivity in (b) Varanasi area, U.P. (India), (c) Saharanpur area, U.P., India and (d) Rhode Island, USA. 

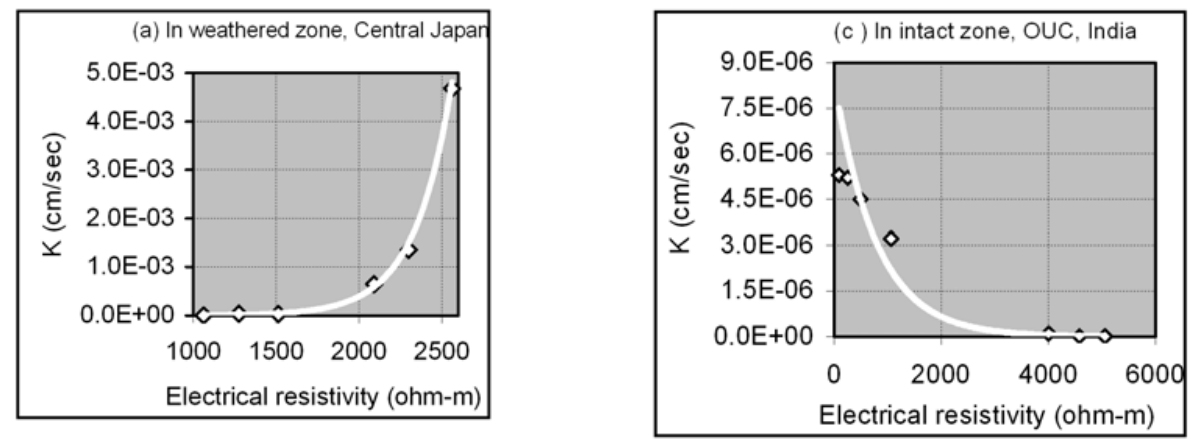

2, 917-938, 2005

\section{Nonlinear estimation of aquifer parameters}

K. P. Singh

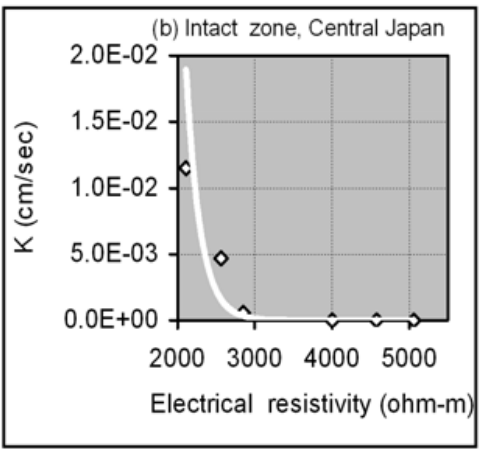

Fig. 3. Correlation analysis of hard rock aquifers. Aquifer permeability (a) increases for weathered rock, but decreases in unweathered, intact aquifers with increasing resistivity both for (b) Central Japan, and (c) OUC, Hyderabad, A. P. (India) data.

Title Page

\section{Abstract}

Introduction

Conclusions

References

Tables

Figures

14

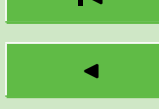

Back

Full Screen / Esc

Print Version

Interactive Discussion

EGU 


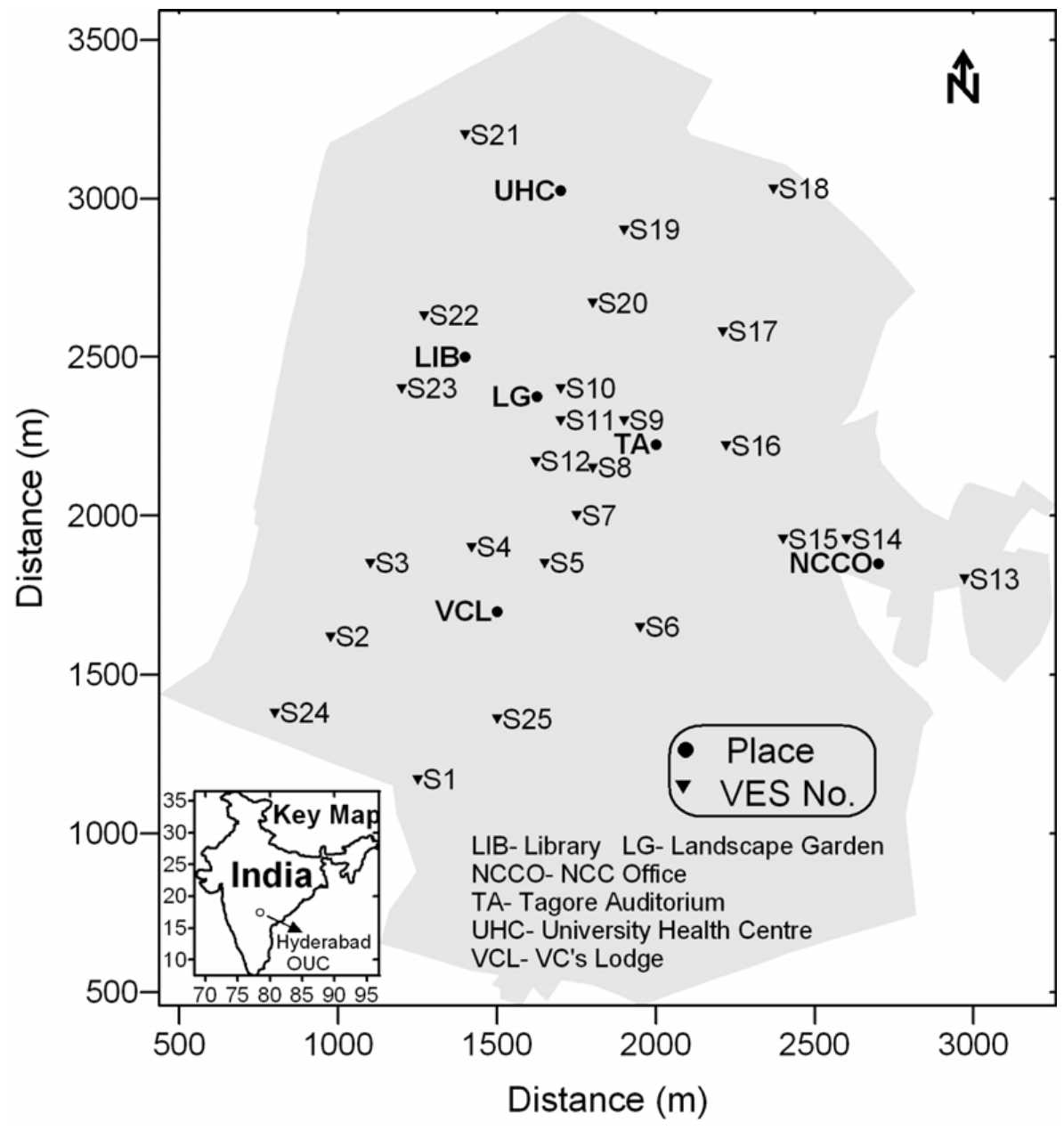

HESSD

2, 917-938, 2005

Nonlinear estimation of aquifer parameters

K. P. Singh

\section{Title Page}

\section{Abstract}

Conclusions

Tables
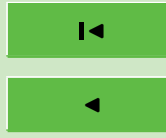

Back
Introduction

References

Figures

$\rightarrow$

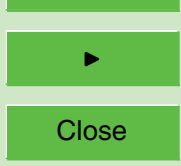

Full Screen / Esc

Print Version

Interactive Discussion

EGU

Fig. 4. Location map of OUC, Hyderabad showing VES and important places. 


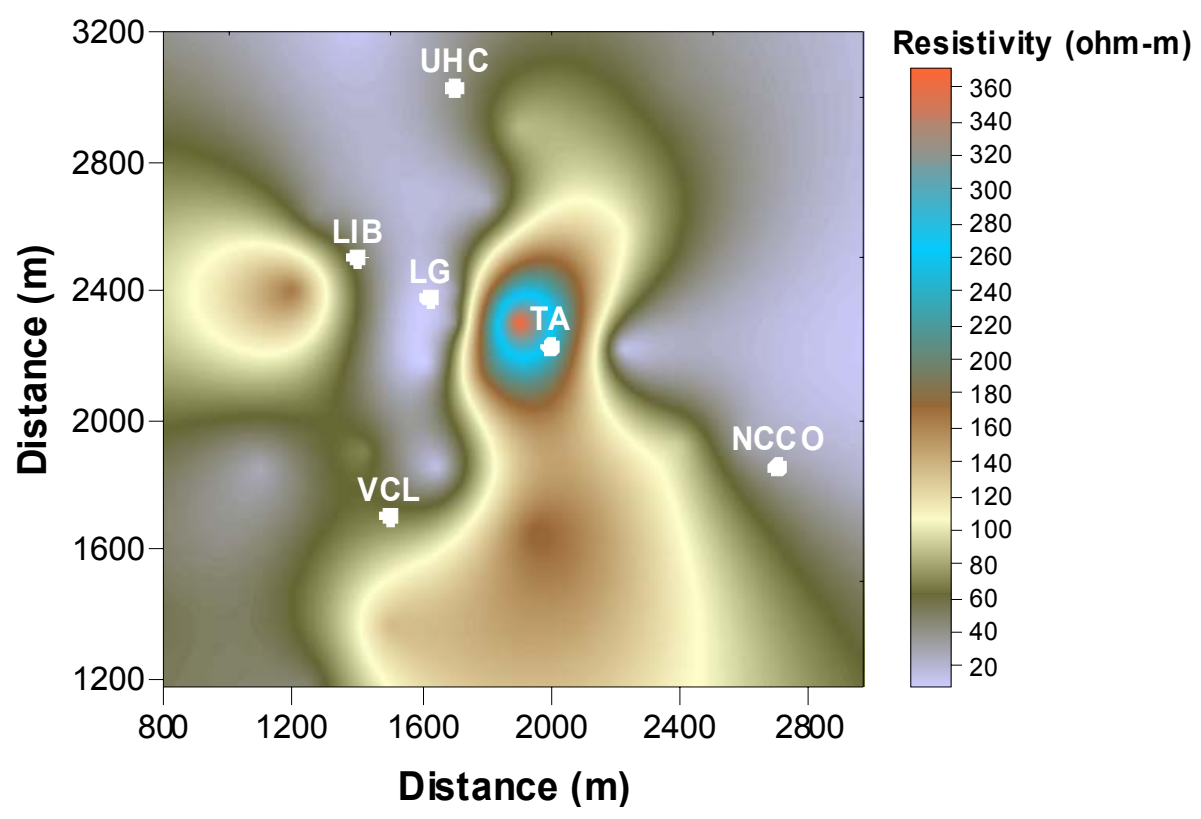

Fig. 5. Resistivity map of the aquifer obtained from interpretation of VES data.

\section{Nonlinear estimation of aquifer parameters}

K. P. Singh

Title Page

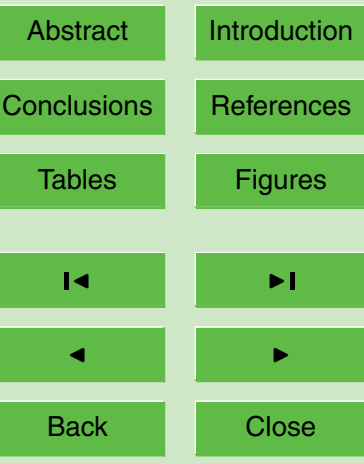

Full Screen / Esc

Print Version

Interactive Discussion

EGU 
2, 917-938, 2005

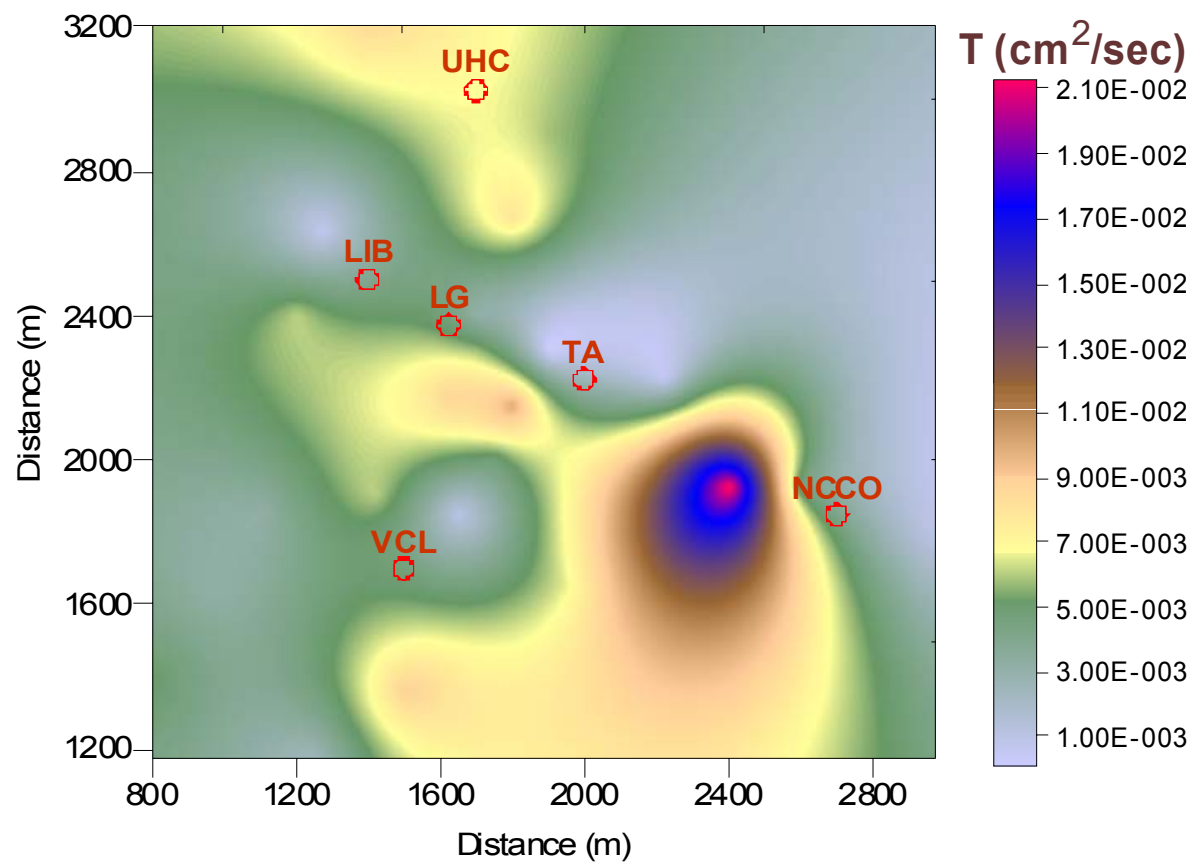

Fig. 6. Transmissivity distribution map of the aquifer in OUC, Hyderabad.
Nonlinear estimation of aquifer parameters

K. P. Singh

Title Page

Abstract

Introduction

Conclusions

References

Tables

Figures

14

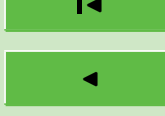

Back

Full Screen / Esc

Print Version

Interactive Discussion 